\title{
A Rare Case of Cranial Polyneuritis as Complication of Ramsay Hunt Syndrome
}

\author{
Jonathan KURNIA WIJAYA', Hendra WIJAYA WONG ${ }^{1}$ \\ ${ }^{1}$ Cilegon General Hospital, Cilegon, Banten, Indonesia \\ *Correspondence: Johnatan Kurnia Wijaja, E-mail: jonathankurnia@hotmail.com \\ UDC 616.523:616.8-009 \\ UDC 616.28:616.5-002.1
}

\begin{abstract}
Ramsay Hunt Sydnrome is a rare and severe disease caused by the reactivation of varicella zoster virus (VZV) in the ganglia geniculate. The classic triad of this disease includes ear pain (otalgia), vesicles in the auditory canal, and facial paralysis. This case report is about a 37-year-old woman that has the classic triad of Ramsay Hunt Syndrome, as well as a rare complication of cranial polyneuritis in the form of cephalgia and vertigo which occurs only in $1.8 \%$ of cases. The patient came one week after the initial symptoms had started and was given antiviral combination therapy and steroids. Treatment of this disease is time sensitive to $<72$ hours and will determine the prognosis. One month later the follow up showed sequelae in the form of persistent headache and slight facial paralysis as a result of delayed treatment. This case report showed the importance of prompt diagnosis and treatment to minimize complications of Ramsay Hunt Syndrome.
\end{abstract}

Key words: Cranial Nerve Diseases; Herpes Zoster Oticus; Neuritis; Signs and Symptoms; Diagnosis; Antiviral Agents; Rare Diseases

\section{Background}

Ramsay Hunt Syndrome, also known as herpes zoster oticus, is a rare and severe disease caused by the reactivation of varicella zoster virus (VZV) in the ganglia geniculate and consists of a classic triad of ear pain (otalgia), vesicles in the external auditory ca-

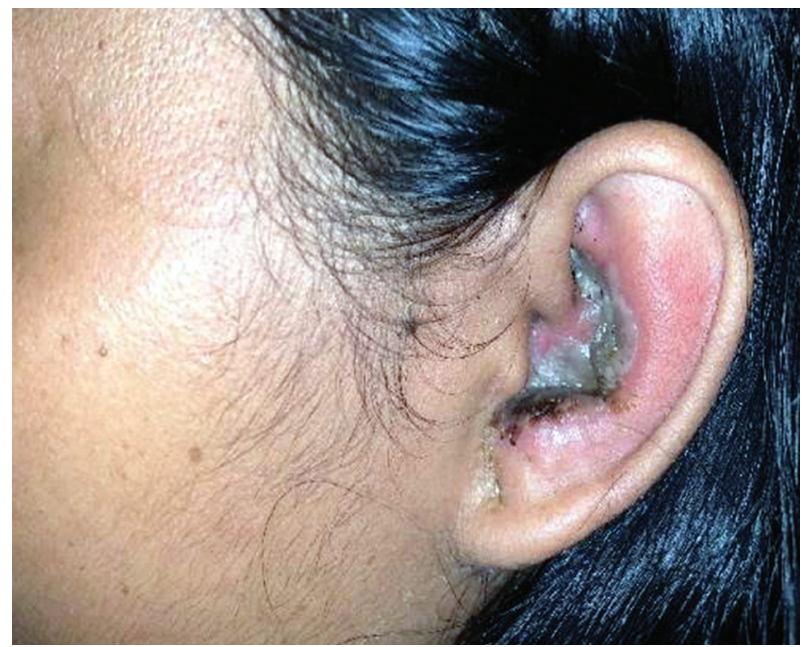

Figure 1. Swelling and ruptured vesicles nal, and facial paralysis (1). The mechanism of this disease is not yet fully understood, but it is commonly associated with immunocompromised and elderly patients $(1,2)$. Nervus (N.) VII paralysis resulting in facial paralysis in Ramsay Hunt Syndrome is characterized as peripheral and ipsilateral usually followed

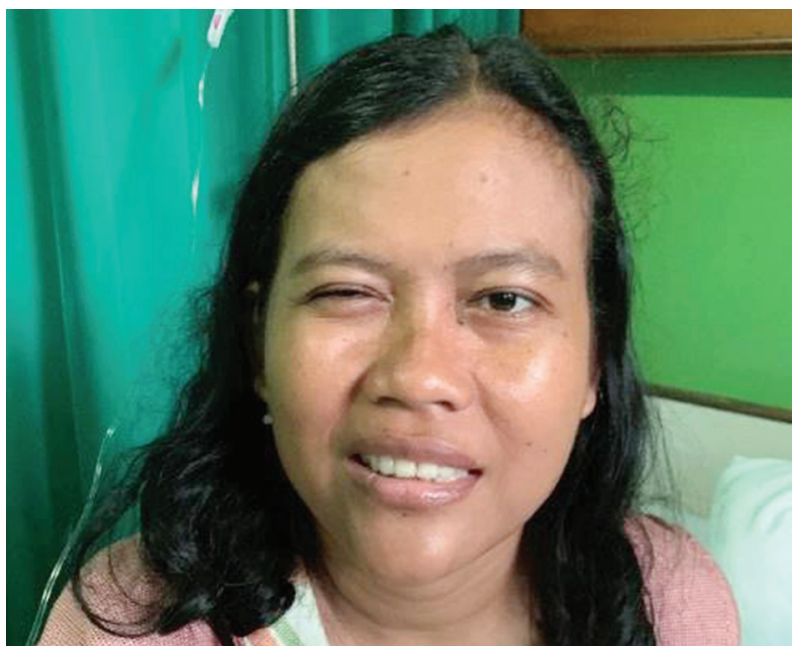

Figure 2. Left side peripheral facial paralysis 


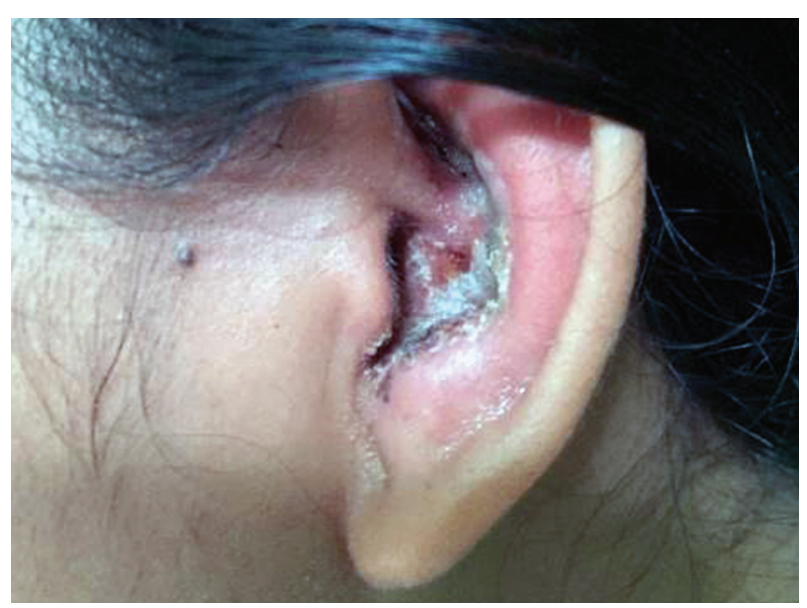

Figure 3. Improvement in swelling

with neuropatic pain (3-5). Other neurological symptoms that may occur are vertigo, headache, tinitus, loss of hearing, and postural imbalance (2-4). Although rare, it could also cause abnormalities in N. V, IX, X and XII (1, $2,6)$. Dermatological symptom is usually localized in the external auditory canal with inflamed itchy vesicles that could rupture to form crusts and scales. Diagnosis of this disease is mostly clinical and unlike mono antiviral therapy in herpes zoster, combination therapy of antiviral and steroids is proven to be more effective, both in dermatological and neurological improvements $(1,3,4,6)$.

\section{Case Report}

A 37-year old women was admitted into the emergency room with a chief complaint of otalgia, which had started one week prior

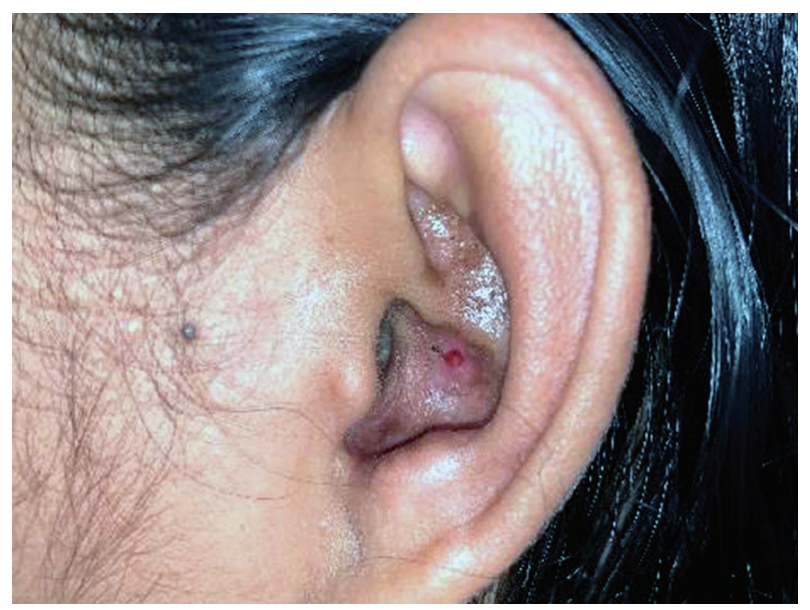

Figure 5. 1 month after treatment

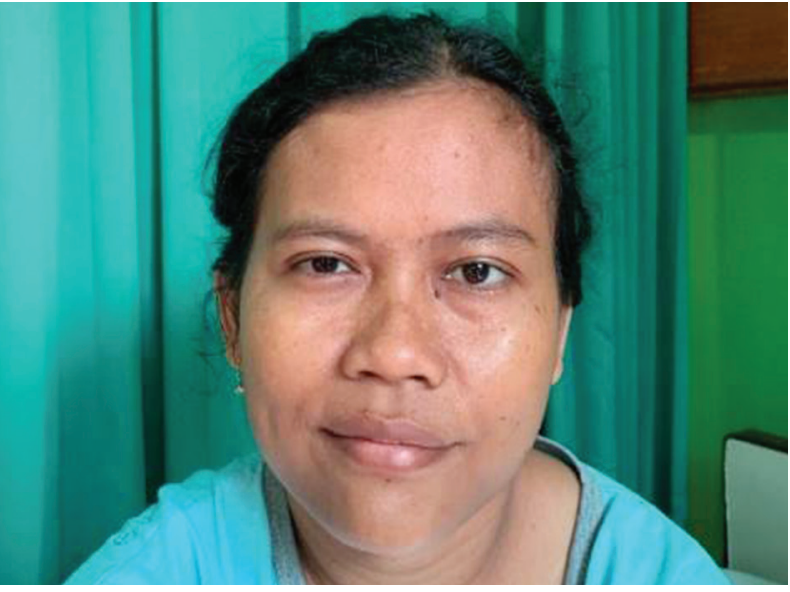

Figure 4. Improvement in facial paralysis

to admission. It started with an itchy painful papule in the external auditory canal that enlarged and evolved into erythematous vesicular rash that eventually ruptured (Figure 1). There was no hearing loss or tinitus with symptoms occuring only on the right side of the ear. The pain so was excruciating that the patient experienced headaches and dizziness, postural imbalance, nausea, and vomiting. Moreover, the patient then experienced peripheral facial paralysis on the left side two days after the initial otalgia with difficulties in closing her mouth and chewing (Figure 2). According to her previous medical history, the patient had varicella when she was nine years old without any history of herpes zoster. Neurological examination revealed that abnormalities were present at N. VII as well as multiple cranial neuritis of N. V and VIII indicated cephalgia, vertigo, and postural imbalance.

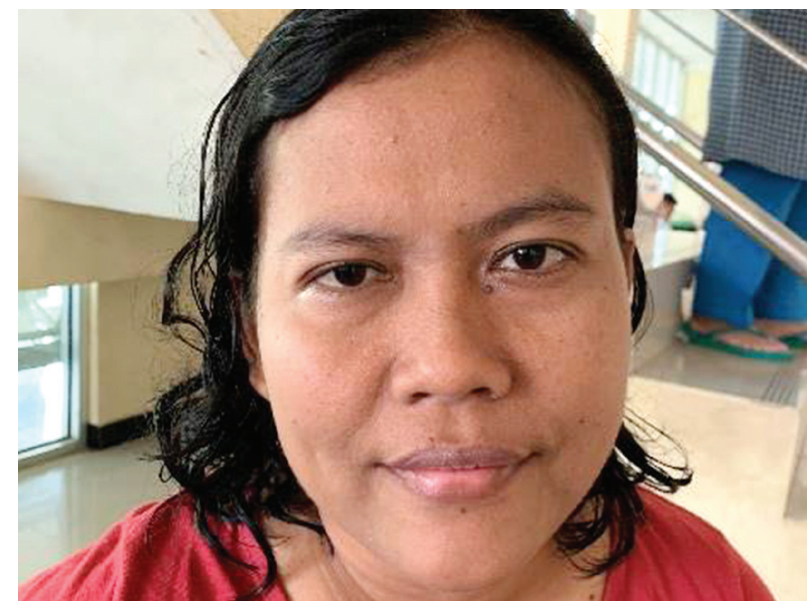

Figure 6. Sequlae of slight facial paralysis 
The patient was then treated with a combination therapy of oral acyclovir at a dosage of $5 \times 800 \mathrm{mg}$ and intravenous (IV) injection of dexamethasone $2 \times 10 \mathrm{mg}$ for 3 days. Subsequently, adjuvant drugs of amitriptilin 12.5 $\mathrm{mg}$ daily and gabapentin $300 \mathrm{mg}$ daily, which was then increased to twice a day, was also given. One day after the initial therapy the patient showed dramatic clinical improvements (Figures 3 and 4). The therapy was then continued for 3 days before the patient was discharged from the hospital. The antiviral therapy was continued until 10 days in addition with gabapentin $300 \mathrm{mg}$ twice a day. The check-up after one month showed that the swelling and vesicles had completely resolved (Figures 5 and 6). However, the patient still had slight facial paralysis and frequently experienced cephalgia and vertigo.

\section{Discussion}

Ramsay Hunt Syndrome is a rare and severe complication resulting from the reactivation of VZV with an incidence rate of about $5 / 100.000$ people in the US (5). The pathophysiology of this disease is not yet clearly understood but it is believed that the reactivation of VZV induces inflammation of cranial nerves resulting in facial paralysis and formation of vesicles in the external auditory canal. Usually, the diagnosis can be made solely based on clinical symptoms. In this case, the patient showed not only all of the symptoms of Ramsay Hunt Syndrome triad, but cranial polyneuritis as well, which occurs only in 1.8\% of all Ramsay Hunt Syndrome cases. Symptoms of cranial polyneuritis may vary; whereas in this case the patient presented with cephalgia and vertigo (4). It is also noted that in other cases, facial paralysis can precede vesicles and it is commonly misdiagnosed as Bell's Palsy disease or stroke. Thus, it is important to differentiate it from other diseases with peripheral or central facial palsy. A simple way to determine it is by examining the forehead, where in cases of peripheral nerve palsy, the forehead would remain unaffected $(4,7)$. Literature also emphasizes the importance of antiviral combination therapy and steroids in treating Ramsay Hunt Syndrome unlike the antiviral monotherapy of herpes zoster. Such a combination can contribute not only in the reduction of the symptoms due to the anti-inflamatory properties of corticosteroid, but also in the reduction of extensive nerve damage, with the resulting improvement in the patient's quality of life as demonstrated in this case. Steroids are also proven to lower the rate of complications such as post-herpetic neuralgia and permanent face paralysis (7-9). Nonetheless, after 1 month of therapy the patient still experienced sequlaes of headaches and nausea. This can be linked with poor prognosis in patients who are treated as late as 72 hours or longer after the onset due to its time sensitive nature with only a $20 \%$ rate of complete symptoms resolution compared to $70 \%$ if treated early $(7,8,10)$. This case report demonstrates that Ramsay Hunt Syndrome can be associated with multiple cranial neuritis which must be differentiated from other neurological diseases. Early diagnosis and prompt treatment are crucial because delayed treatment could result in prolonged recovery or even permanent nerve damage.

\section{Conclusion}

Ramsay Hunt Disease is a rare disease that can be sometimes misdiagnosed as other diseases. It is a result of the reactivation of VZV that has a time sensitive prognosis wirh greater prognosis if treated within 72 hours after the initial onset. The combination therapy of antiviral and steroids is proven to be effective not only in the reduction of symptoms, but also in lowering the complication rate and improving the patient's quality of life.

\section{References}

1. Worme M, Chada R, Lavallee L. An unexpected case of Ramsay Hunt syndrome: case report and literature review. BMC Res Notes. 2013;6:337.

2. Fitzpatrick TB, Goldsmith LA, Wolff K. Fitzpatrick's dermatology in general medicine. 8th ed. New York: McGraw Hill; 2012. p. 2383-400.

3. Zheng RW, Liu D, Eric TE, Ning YZ, Chen LL, Hu H, et al. A case study of Ramsay Hunt Syndrome in conjunction with cranial polyneuritis. Medicine. 2017;96(47):e8833.

4. Garro A, Nigrovic LE. Managing peripheral facial palsy. Ann Emerg Med. 2018;71(5):618-24.

5. Magalhaes M, Cardoso MS, Gontijo I. Ramsay hunt syndrome - case report. Revista Brasileira de Neurologia e Psiquiatria. 2014;18(3):247-52.

6. Jeon Y, Lee H. Ramsay Hunt syndrome. J Dent Anesth Pain Med. 2018;18(6):333-7. 
7. Sweeney CJ, Gilden DH. Ramsay Hunt syndrome. J Neurol Neurosurg Psychiatry. 2001;71(2):149-54.

8. Monsanto RD, Bittencourt AG, Bobato Neto NJ, Beilke SC, Lorenzetti FT, Salomone R. Treatment and prognosis of facial palsy on Ramsay Hunt syndrome: results based on a review of the literature. Int Arch Otorhinolaryngol. 2016;20(4):394-400.
9. Montague SJ, Morton AR. Ramsay Hunt syndrome. CMAJ. 2017;189(8):E320.

10. Waldman RA, Waldman CW, Waldman SD. Ramsay Hunt syndrome type 2: a review of an uncommon and unwelcome neurodermatologic disease. Journal of Otolaryngology and Rhinology. 2015;1(1):1-4.

\section{Redak slučaj kranijalnog polineuritisa kao komplikacije sindroma Remzija Hunta}

\section{Sažetak}

Sindrom Remzija Hanta (Ramsay Hunt's syndrome) je retko i teško oboljenje izazvano reaktivacijom virusa varičela zoster u genikulatnim ganglionima. Klasična trijada ovog oboljenja obuhvata bol u uvu (otalgija), vezikule u ušnom kanalu i facijalnu paralizu. Ovde prikazujemo slučaj žene stare 37 godina koja ima klasičnu trijadu sindroma Remzija Hanta kao i retku komplikaciju kranijalnog polineuritisa u obliku cefalgije i vertiga što se javlja u samo $1,8 \%$ slučajeva. Pacijentkinja je došla nedelju dana posle početka prvih simptoma i dobila je antivirusnu kombinovanu terapiju i steroide. Lečenje ove bolesti je vremenski osetljivo ( $<72$ sata) $i$ odrediće prognozu. Kontrolni pregled nakon mesec dana pokazao je sekvele u obliku uporne glavobolje i blage facijalne paralize što je rezultat odgođenog lečenja. Ovaj prikaz slučaja ukazuje na značaj blagovremene dijagnoze i lečenja kako bi se komplikacije sindroma Remzija Hanta svele na minimum.

Ključne reči: Bolesti kranijalnih nerava; Ušni herpes zoster; Neuritis; Znaci i simptomi; Dijagnoza; Antivirusni lekovi; Retke bolesti

Received 12.10.2019.

Accepted 6.11.2019. 